\title{
Association between menarche age and menstrual disorder with the incidence of uterine fibroid in medan, Indonesia: based on hospital data
}

\author{
Muhammad Fidel Ganis Siregar*
}

Division of Reproductive Endocrinology and Fertility, Department of Obstetrics and Gynecology, Faculty of Medicine, Universitas Sumatera Utara

Received: 11 May 2015

Accepted: 06 June 2015

\section{*Correspondence:}

Dr. Muhammad Fidel Ganis Siregar,

E-mail: fgsiregar@gmail.com

Copyright: $\odot$ the author(s), publisher and licensee Medip Academy. This is an open-access article distributed under the terms of the Creative Commons Attribution Non-Commercial License, which permits unrestricted non-commercial use, distribution, and reproduction in any medium, provided the original work is properly cited.

\section{ABSTRACT}

Background: Uterine fibroids are benign, monoclonal tumors of the smooth muscle cells found in the human uterus. The incidence of uterine fibroid in Indonesia is between $2.39 \%-11.7 \%$ in all gynecology inpatient. Despite the fact that their cause is still unknown, there is considerable evidence that estrogens and progestogens proliferate tumor growth, as the fibroids rarely appear before menarche and regress after menopause.

Methods: An observational analytic study with case control approach. Total sample from this study was 498 people, with 249 cases and 249 controls. The samples were collected through purposive sampling. The study was conducted in the medical record division of Adam Malik General Hospital Medan. Results from the study were analyzed with chi square.

Results: The result of this study demonstrated an association between menarche age with uterine fibroid incidence, with a p-value $<0.05$, and odds ratio $=2.487$ (CI 1.585-3.902). This indicate that the incidence of uterine fibroid is 2.5 greater in women with menarche age of $<10$ years old. P-value $<0.05$ and odds ratio $=0.258$ (CI 0.178-0.375) were obtained from the association between menstrual disorder and uterine fibroid incidence.

Conclusions: The result of this study demonstrates a significant association correlation between menarche age and the development of uterine fibroid. Early menarche age increases risk of uterine fibroid incidence, whereas menstrual disorder is more likely a clinical manifestation of uterine fibroid, rather than a risk factor.

Keywords: Menarche age, Menstrual disorder, Uterine fibroid

\section{INTRODUCTION}

Uterine fibroids (myomas or leiomyomas) are benign, monoclonal tumors of the smooth muscle cells found in the human uterus. ${ }^{1,2}$ Despite the fact that their cause is still unknown, there is considerable evidence that estrogens and progestogens proliferate tumor growth, ${ }^{3,4}$ as the fibroids rarely appear before menarche and regress after menopause.$^{5,6}$ Uterine fibroids are the most common benign tumors in women and the leading indication for hysterectomies in the USA, ${ }^{7,8}$ nevertheless, epidemiological data on fibroid prevalence and incidence are limited and reliable population-based research is lacking. ${ }^{9}$ Available data are difficult to compare due to differences in the study population and screening methods. Prevalence data range from $5 \%$ to $21 \% .^{10-16}$ The majority of women with uterine fibroids are asymptomatic, consequently get less clinical attention and fibroid tumors often remain undiagnosed. ${ }^{17,18}$ Symptomatic women typically complain about abnormal uterine bleeding, specifically in terms of heavy and prolonged bleeding. ${ }^{19}$ Early age at menarche has been associated with several health complications, including higher risk for obesity, cardiovascular disease, metabolic syndrome, type 2 diabetes, preeclampsia, and various forms of cancer. ${ }^{20-29}$ Prior studies have identified early 
age at menarche as a risk factor for the development of uterine leiomyoma, or fibroids. ${ }^{30-35}$ The incidence of uterine fibroid in Indonesia was found to be between $2.39 \%-11.7 \%$ in all of gynecology inpatient. ${ }^{1}$ About $20 \%$ or one in five women suffer from uterine fibroid. Therefore, routine gynecological examination is very important for women in reproductive age. ${ }^{36}$ Indonesia is an archipelago country with many remote and rural areas which is not covered by medical facilities. Moreover, the average level of education and economy in Indonesia is still low, affecting the availability and affordability of medical examination. By screening the patient based on risk factor (menarche age), targeted gynecological examination for uterine fibroid could be done. Based on a preliminary survey conducted at Adam Malik General Hospital Medan, incidence of uterine fibroid increased from 110 patients in 2011 to 168 patients in 2012.

\section{METHODS}

This study was conducted in the medical record division of Adam Malik General Hospital Medan, Indonesia from 20 March 2012 to 19 April 2014.

This is an observational analytic study with a case control approach. The samples in this study were women diagnosed with benign gynecological tumor based on post surgery histopathological result at Adam Malik General Hospital Medan in 2012-2014 who met the inclusion criteria, such as age $>20$ years, no familial history of uterine fibroid and willing to participate in the study. Menstrual disorder symptoms were obtained from the patient's history in medical record. Definition of menstrual disorder in this study is any alteration in menstrual pattern including heavy menstrual bleeding, prolonged menstruation or menstrual pain.

Total sample from this study was 498 people, with 249 uterine fibroid cases and 249 patients with other benign gynecological tumor. The samples were collected through purposive sampling.

The independent variables in this study were menarche age and menstrual disorder. The dependent variables were uterine fibroid. The analysis that used were univariate analysis and bivariate analysis. Univariate analysis was completed using frequency distribution table, while bivariate analysis was completed using chi square test and then the risk factor was subsequently analysed using odds ratio. All of the statistical analysis in this study was performed using SPSS ${ }^{\mathrm{TM}}$ program.

\section{RESULTS}

Based on the study conducted at Adam Malik General Hospital Medan in 2012 - 2014, the following results were obtained:

Based on Table 1, from 249 uterine fibroid patients in this study, 177 patients $(35.5 \%)$ had menarche at $>10$ years old, whereas the majority of patients with other benign tumor had menarche at $>10$ years old with 214 patients $(43.0 \%)$

Table 1: frequency distribution of benign gynecological tumor based on menarche age at $\mathrm{H}$. Adam Malik General Hospital Medan in 2012-2014.

\begin{tabular}{|llllllll|}
\hline \multirow{2}{*}{ No $\begin{array}{l}\text { Menarche } \\
\text { Age }\end{array}$} & \multicolumn{6}{l|}{$\begin{array}{l}\text { Benign Gynecological Tumor } \\
\text { Uterine Fibroid }\end{array}$} & \multicolumn{2}{l|}{ Non Fibroid } & \multicolumn{2}{c|}{ Total } \\
\hline 1 & F & $\%$ & F & $\%$ & F & $\%$ \\
\hline $\begin{array}{l}\text { < 10 Years } \\
\text { Old }\end{array}$ & 72 & 14.5 & 35 & 7.0 & 107 & 21.5 \\
\hline 2 & $\begin{array}{l}>\text { 10 Years } \\
\text { Old }\end{array}$ & 177 & 35.5 & 214 & 43.0 & 391 & 78.5 \\
\hline & Total & 249 & 50.0 & 249 & 50.0 & 498 & 100 \\
\hline
\end{tabular}

Table 2: Frequency distribution of uterine fibroid incidence based on menstrual disorder at $\mathrm{H}$. Adam Malik General Hospital Medan in 2012-2014.

\begin{tabular}{|c|c|c|c|c|c|c|c|}
\hline \multirow{3}{*}{ No } & \multirow{3}{*}{$\begin{array}{l}\text { Menstrual } \\
\text { Disorder }\end{array}$} & \multicolumn{6}{|c|}{ Benign Gynecological Tumor } \\
\hline & & \multicolumn{2}{|c|}{ Uterine Fibroid } & \multicolumn{2}{|c|}{ Non Fibroid } & \multicolumn{2}{|c|}{ Total } \\
\hline & & $\mathbf{F}$ & $\%$ & $\mathbf{F}$ & $\%$ & $\mathbf{F}$ & $\%$ \\
\hline 1 & Not present & 90 & 18.1 & 171 & 34.3 & 261 & 52.4 \\
\hline 2 & Present & 159 & 31.9 & 78 & 15.7 & 237 & 47.6 \\
\hline & Total & 249 & 50.0 & 249 & 50.0 & 498 & 100 \\
\hline
\end{tabular}

From table 2, the majority of fibroid patients experienced menstrual disorder with 159 patients $(31.9 \%)$, whereas the majority of non fibroid group were without menstrual disorder with 171 patients $(34.3 \%)$.

Table 3: Association between menarche age and uterine fibroid incidence at H. Adam Malik General Hospital Medan in 2012-2014.

\begin{tabular}{|c|c|c|c|c|c|c|c|c|}
\hline \multirow{3}{*}{ No } & \multirow{3}{*}{ Menarche Age } & \multicolumn{7}{|c|}{ Benign Gynecological tumor } \\
\hline & & \multicolumn{2}{|c|}{ Uterine fibroid } & \multicolumn{2}{|c|}{ Non Fibroid } & \multirow[t]{2}{*}{$\mathbf{P}$} & \multirow[t]{2}{*}{ OR } & \multirow[t]{2}{*}{$\begin{array}{l}\text { CI } \\
95 \%\end{array}$} \\
\hline & & $\mathbf{F}$ & $\%$ & $\mathbf{F}$ & $\%$ & & & \\
\hline 1 & $<10$ Years Old & 72 & 14.5 & 35 & 7 & & & \\
\hline 2 & $>10$ Years Old & 177 & 35.5 & 214 & 43 & 0.0001 & 2.487 & $\begin{array}{l}1.585 \\
3.902\end{array}$ \\
\hline & Total & 249 & 50 & 249 & 50 & & & \\
\hline
\end{tabular}


Table 4: Association between menstrual disorders and uterine fibroid incidence at $\mathbf{H}$. Adam Malik General Hospital Medan in 2012-2014.

\begin{tabular}{|c|c|c|c|c|c|c|c|c|}
\hline \multirow{3}{*}{ No } & \multirow{3}{*}{$\begin{array}{l}\text { Menstrual } \\
\text { Disorder }\end{array}$} & \multicolumn{7}{|c|}{ Benign Gynecological Tumor } \\
\hline & & \multicolumn{2}{|c|}{ Uterine Fibroid } & \multicolumn{2}{|c|}{ Non Fibroid } & \multirow[t]{2}{*}{$\mathbf{P}$} & \multirow[t]{2}{*}{ OR } & \multirow{2}{*}{$\begin{array}{l}\text { CI } \\
95 \%\end{array}$} \\
\hline & & $\mathbf{F}$ & $\%$ & f & $\%$ & & & \\
\hline 1 & Not Present & 90 & 18.1 & 171 & 34.3 & & & \\
\hline 2 & Present & 159 & 31.9 & 78 & 15.7 & 0.000 & 0.258 & $\begin{array}{l}0.178 \\
0.345\end{array}$ \\
\hline & Total & 249 & 50 & 249 & 50 & & & \\
\hline
\end{tabular}

Table 3 shows the association between menarche age and uterine fibroid incidence. A p-value $<0.0001$ can be identified, signifying an association between menarche age and uterine fibroid incidence. An odds ratio of 2.487 (CI 1.585-3.902) denotes women with menarche at $<10$ years old have a 2.487 times higher chance of having uterine fibroid. Confidence interval of 1.585-3.902 supported the odds ratio interval with menarche and uterine fibroid.

Table 4 demonstrated the computer-analysed study results of association between menstrual disorders and uterine fibroid incidence. A p-value $<0.0001$ can be identified, signifying an association of menstrual disorders in uterine fibroid and other benign gynecological tumor incidence. An odds ratio of 0.258 (CI 0.178-0.345) denotes women with menstrual disorder have a 0.258 times higher chance of having uterine fibroid. Confidence interval of 0.178 0.345 illustrated odds ratio interval. This mean that menstrual cycle is a protective factor for fibroid.

\section{DISCUSSION}

Fibroid developed in women with earlier and longer exposure to estrogen, such as in women with early menarche. The great amount of estrogen in the blood of women with fibroid and without fibroid were the same, however the amount of estradiol in women with fibroid were higher compared to women without fibroid. This is because women with uterine fibroid have a lesser amount of enzyme that could convert estradiol to estrone, therefore the amount of estradiol is greater and will enhance fibroid growth. This view is supported in a study by Victory et al which said that increase of uterine fibroid growth were a response of estrogen stimulus. Marshal et al and Faerstin stated significant increase in uterine fibroid incidence in women with menarche prior to 11 years old. The longer exposure to estrogen will increase uterine fibroid incidence. Early menarche $(<10$ years) were found to increase uterine fibroid's relative risk, and late menarche (>16 years) decreased uterine fibroids relative risk. ${ }^{5}$

\section{CONCLUSION}

Based on this study results, we can conclude that the majority of patient with uterine fibroid had menarche at < 10 years old. Woman with menarche at $<10$ years old is 2.5 times more likely to develop a uterine fibroid than woman with menarche at $>10$ years old.
Menstrual disorder in patient with uterine fibroid is more likely a manifestation of this disease, rather than the risk factor for the development of uterine fibroid.

The result in this study warrant a complete and routine gynecological examination in women with early menarche, especially in Indonesian women.

\section{ACKNOWLEDGEMENTS}

Sincere thanks and appreciation to Prof. Dr. Delfi Lutan, MSc, SpOG.K our Head Department of Obstetric and Gynaecology Department at Universitas Sumatera Utara, Medan ,Indonesia for every support ,guidence and advices.

Funding: No funding sources Conflict of interest: None declared

Ethical approval: The study was approved by the Institutional Ethics Committee

\section{REFERENCES}

1. Parker WH. Etiology, symptomatology, and diagnosis of uterine myomas. Fertil Steril. 2007;87(4):725-36.

2. Kempson RL, Hendrickson MR. Smooth muscle, endometrial stromal, and mixed Müllerian tumors of the uterus. Mod Pathol. 2000;13(3):328-42.

3. Rein MS, Barbieri RL, Friedman AJ. Progesterone: a critical role in the pathogenesis of uterine myomas. Am J Obstet Gynecol. 1995;172(1 Pt1):14-8.

4. Andersen J. Growth factors and cytokines in uterine leiomyomas. Semin Reprod Endocrinol. 1996;14(3):269-82.

5. Fields KR, Neinstein LS. Uterine myomas in adolescents: case reports and a review of the literature. J Pediatr Adolesc Gynecol. 1996;9(4):195-8.

6. Cramer SF, Patel A. The frequency of uterine leiomyomas. Am J Clin Pathol. 1990;94(4):435-8.

7. Farquhar CM, Steiner CA: Hysterectomy rates in the United States 1990- 1997. Obstet Gynecol. 2002;99(2):229-34.

8. Merrill RM: Hysterectomy surveillance in the United States, 1997 through 2005. Med Sci Monit. 2008;14(1):CR24-CR31.

9. Laughlin SK, Schroeder JC, Baird DD. New directions in the epidemiology of uterine fibroids. Semin Reprod Med. 2010, 28(3):204-17. 
10. Laughlin SK, Baird DD, Savitz DA, Herring AH, Hartmann KE. Prevalence of uterine leiomyomas in the first trimester of pregnancy: an ultrasound screening study. Obstet Gynecol. 2009;113(3):630-5.

11. Chen CR, Buck GM, Courey NG, Perez KM, Wactawski-Wende J. Risk factors for uterine fibroids among women undergoing tubal sterilization. Am J Epidemiol. 2001;153(1):20-6.

12. Borgfeldt C, Andolf E: Transvaginal ultrasonographic findings in the uterus and the endometrium: low prevalence of leiomyoma in a random sample of women age 25-40 years. Acta Obstet Gynecol Scand. 2000;79(3):202-7.

13. Marino JL, Eskenazi B, Warner M, Samuels S, Vercellini P, Gavoni N, et al. Uterine leiomyoma and menstrual cycle characteristics in a population based cohort study. Hum Reprod. 2004;19(10):2350-5.

14. Parazzini F, Negri E, La Vecchia C, Chatenoud L, Ricci E, Guarnerio P. Reproductive factors and risk of uterine fibroids. Epidemiology. 19967(4):440-2.

15. Parazzini F. Risk factors for clinically diagnosed uterine fibroids in women around menopause. Maturitas. 2006;55(2):174-9.

16. Lumbiganon $\mathrm{P}$, Rugpao $\mathrm{S}$, Phandhu-fung $\mathrm{S}$, Laopaiboon M, Vudhikamraksa N, Werawatakul Y. Protective effect of depot medroxyprogesterone acetate on surgically treated uterine leiomyomas:a multicentre case-control study. Br J Obstet Gynaecol. 1996;103(9):909-14.

17. Schwartz SM, Marshall LM, Baird DD. Epidemiologic contributions to understanding the etiology of uterine leiomyomata. Environ Health Perspect. 2000;108(Suppl 5):821-7.

18. Okolo S. Incidence, aetiology and epidemiology of uterine fibroids. Best Pract Res Clin Obstet Gynaecol. 2008;22(4):571-88.

19. Ryan GL, Syrop CH, Van Voorhis BJ. Role, epidemiology, and natural history of benign uterine mass lesions. Clin Obstet Gynecol. 2005;48(2):31224.

20. Chavarro J, Villamor E, Narvaez J, et al. Sociodemographic predictors of age at menarche in a group of Colombian university women. Ann Hum Biol. 2004;31(2):245-57.

21. de Vries MJ, Dekker GA, Schoemaker J. Higher risk of preeclampsia in the polycystic ovary syndrome. A case control study. Eur J Obstet Gynecol Reprod Biol. 1998;76(1):91-5.

22. Freedman DS, Khan LK, Serdula MK, et al. The relation of menarcheal age to obesity in childhood and adulthood: the Bogalusa heart study. BMC Pediatr. 2003;3:3.

23. Lakshman R, Forouhi NG, Sharp SJ, et al. Early age at menarche associated with cardiovascular disease and mortality. J Clin Endocrinol Metab. 2009;94(12):4953-60.
24. Rudra CL, Williams MA. BMI as a modifying factor in the relations between age at menarche, menstrual cycle characteristics, and risk of preeclampsia. Gynecol Endocrinol. 2005;21(4):200-5.

25. Solomon CG, Hu FB, Dunaif A, et al. Menstrual cycle irregularity and risk for future cardiovascular disease. J Clin Endocrinol Metab. 2002;87(5):20137.

26. Veltman-Verhulst SM, van Rijn BB,Westerveld HE, et al. Polycystic ovary syndrome and early-onset preeclampsia: reproductive manifestations of increased cardiovascular risk. Menopause. 2010;17(5):990-6.

27. Abetew DF, Enquobahrie DA, Dishi M, et al. Age at menarche, menstrual characteristics, and risk of preeclampsia. ISRN Obstet Gynecol. 2011;2011: 472083.

28. MacMahon B, Trichopoulos D, Brown J, et al. Age at menarche, urine estrogens and breast cancer risk. Int J Cancer. 1982;30(4):427-31.

29. Pieta B, Chmaj-Wierzchowska K, Opala T. Past obstetric history and risk of ovarian cancer. Ann Agric Environ Med. 2012;19(3):385-8.

30. Dragomir AD, Schroeder JC, Connolly A, et al. Potential risk factors associated with subtypes of uterine leiomyomata. Reprod Sci. 2010;17(11):1029-35.

31. Wise LA, Palmer JR, Harlow BL, et al. Reproductive factors, hormonal contraception, and risk of uterine leiomyomata in African-American women: a prospective study. Am J Epidemiol. 2004;159(2):113-23.

32. Faerstein E, Szklo M, Rosenshein N. Risk factors for uterine leiomyoma: a practice-based case-control study. I. African-American heritage, reproductive history, body size, and smoking. Am J Epidemiol. 2001;153(1):1-10.

33. Lumbiganon $\mathrm{P}$, Rugpao $\mathrm{S}$, Phandhu-fung $\mathrm{S}$, et al. Protective effect of depot-medroxyprogesterone acetate on surgically treated uterine leiomyomas: a multicentre case-control study. Br J Obstet Gynaecol. 1996;103(9):909-14.

34. Marshall LM, Spiegelman D, Goldman MB, et al. A prospective study of reproductive factors and oral contraceptive use in relation to the risk of uterine leiomyomata. Fertil Steril. 1998;70(3):432-9.

35. Samadi AR, Lee NC, Flanders WD, et al. Risk factors for self-reported uterine fibroids: a case-control study. Am J Public Health. 1996;86(6):858-62.

36. Muzakir. Profil Penderita Mioma Uteri di RSUD Arifin Achmad Provinsi Riau Periode 1 Januari-31 Desember 2006. Faculty of Medicine - University Riau; 2008.

Cite this article as: Siregar MFG. Association between menarche age and menstrual disorder with the incidence of uterine fibroid in medan, Indonesia: based on hospital data. Int J Reprod Contracept Obstet Gynecol 2015;4:1025-8. 